RESEARCH ARTICLE

\title{
Effect of Maturity Stages on Seed Quality in Winged Bean [Psophocarpus tetragonolobus (L.) DC.] - a Multipurpose Legume
}

\author{
Sakthivel $\mathbf{S}^{1}$, Renugadevi ${ }^{\mathbf{1}^{*}}$, Raja $\mathrm{K}^{1}$ and Swarnapriya $\mathbf{R}^{\mathbf{2}}$ \\ ${ }^{1}$ Department of Seed Science and Technology, Tamil Nadu Agricultural University, Coimbatore - 641003. \\ ${ }^{2}$ Department of Vegetable Science, HC \& RI, Tamil Nadu Agricultural University, Coimbatore - 641003.
}

Received : 21 ${ }^{\text {st }}$ May, 2020

Revised : $29^{\text {th }}$ May, 2020

Revised : $10^{\text {th }}$ June, 2020

Accepted : $17^{\text {th }}$ June, 2020

\begin{abstract}
Winged bean being a multipurpose leguminous vegetable, has been less concentrated in research. Considering its huge potential as a protein-rich crop with soybean-equivalent nutrients, the present study aimed to find out the physiological maturity stage in winged bean cv. Revathy to obtain good quality of seeds for better planting value. The developing pods and seeds of various maturity stages were harvested from 5 days after anthesis (DAA) to 60 DAA at five days interval and determined the pod and seed characteristics. The results showed that pod length, pod weight (fresh and dry weight) increased steeply from 5 DAA to 30 DAA and the maximum pod length $(18.4 \mathrm{~cm})$, and attained pod fresh weight of $27.84 \mathrm{~g} /$ pod at 30 DAA. The physiological maturity of seeds were attained at 50 DAA with seed moisture content of $27.8 \%$ coincided with maximum dry weight of seed ( $32.47 \mathrm{~g} / 100$ seeds), seed protein content (34.7\%) and maximum physiological qualities viz., speed of germination (4.1), germination per cent $(88 \%)$, root length $(17.5 \mathrm{~cm})$, shoot length $(15.7 \mathrm{~cm})$, dry matter production $(0.894 \mathrm{~g} / 10$ seedlings), vigor index I (2922) and vigor index II (72). The visual indices for physiological maturity was turning of pod to brown color and the seed to black group of RHS color chart (202 A) at 50 DAA.
\end{abstract}

Keywords: Winged bean; quality seeds; physiological maturity; germination \%; vigor index.

\section{INTRODUCTION}

In recent years, underutilized crops have attained more attention in global research due to the call for promoting sustainable agricultural production (Massawe et al., 2016). To bridge the gap between the nutritional needs and the quantity of food supply among the human population, the development of underutilized protein-rich legumes is one of the momentous solutions to solve this problems especially in the developing countries where highprotein sources like grains and meat are expensive and scarce (Cheng et al., 2019). Winged bean [Psophocarpus tetragonolobus (L.) DC.] $(2 n=18)$, belonging to the family Fabaceae is one such underutilized multipurpose leguminous vegetable with vast potential of food source (Mahto and Dua, 2009). It is a tropical crop grown widely in Asia, India, Indonesia, Papua New Guinea, and some parts of Africa (Verdcourt and Halliday, 1978). Winged bean is also called Goa bean, four-angled bean, and the presence of wings is the characteristic feature of this crop (NAS, 1981). The Psophocarpus is derived from the Greek words 'Psohos' (noise) and 'Karpus' (fruit), which indicates the explosive noise made during pod dehiscence (Allen and Allen, 1981). This crop is popularly designated as "All-purpose wonder crop," "God-given plant," "One stalk supermarket," or "Single-species supermarket” (Singh et al., 2019) because all parts of the plant including leaves, pods, tuber and even flowers are edible and also the stems and leaves are used as fodder. Pods are used in curry, pickle and salad items. The protein content in seeds (30-40\%) is comparable to soybean, which is about $50 \%$ higher than other legumes and also contains soybean-equivalent nutrients (Amoo et al. 2006). It also contains specific trypsin and chymotrypsin with insecticidal property (Gatehouse et al., 1991) and also contains a good balance of amino acids, including lysine. It helps in increasing soil fertility by fixing atmospheric nitrogen and requires low external inputs (Massawe et al., 2016).

Even though they provide several nutritional security, information on ideal harvest time, and physiological maturity of winged bean seeds are still unknown. As far as the seed quality is concerned, seed development have significant importance. Production of good quality genuine seeds and its maintenance till next planting are very important for commercial cultivation of any crops. According to Marcos-Filho et al. (1994), there is a point at which 
the stabilization of dry matter translocation to the seed is attained, and that point is called physiological maturity. If seeds are harvested at the correct stage of maturity, maximum seed germination, and vigor may be achieved (Vidigal et al., 2011).

According to Copeland and McDonald (1995), delayed harvesting may decline seed quality due to adverse environmental conditions such as high temperature, high humidity, rainfall, over-drying, damage by birds and animals, or attacks by diseases, pests and also causes pod shattering in the field. Moreover, the dormancy of winged bean seed is hard to break, that acts as a barrier to water uptake, gas exchange, or loss of chemical inhibitors (Finkelstein, 2010). Hence, the quality of winged bean seeds depends on harvesting stage and nutrient contents viz., protein, amino acids, carbohydrate, fat, vitamin etc. Therefore, this study was aimed to assess the seed development and maturation pattern in winged bean by monitoring changes in physical and physiological seed quality characters coincided with maximum seed vigor.

\section{MATERIAL AND METHODS}

The experiment was carried out at Department of Seed Science and Technology, Tamil Nadu Agricultural University (TNAU), Coimbatore, India and the crop was raised at orchard, TNAU $\left(11^{\circ}\right.$ 00'30'N latitude, $76^{\circ} 55^{\prime} 50^{\prime \prime} E$ longitude) during the Rabi season of 2019. The seeds of winged bean cv. Revathy obtained from Kerala Agricultural University, Vellanikkara, India formed the base material for this study. The crop was raised as bulk in the field with recommended package of practices (KAU, 2011) and about 250 - 300 individual flowers were tagged daily at the time of anthesis. Pods developed on tagged flowers were harvested at five days intervals from 5 days after anthesis (DAA) until 60 DAA. The experiment design was completely randomized design (CRD) with twelve treatments (DAA) and four replications to each treatment.

At each stage (DAA), the pod length $(\mathrm{cm})$, pod width $(\mathrm{cm})$ and pod fresh weight $(\mathrm{g} / \mathrm{pod})$ were recorded from ten pods of each in four replications. After determining the fresh weight, the pods were bisected longitudinally and then dried in a hot air oven maintained at $80^{\circ} \mathrm{C}$ for 16 hours, until the constant weight was achieved. At the end of the prescribed period, the container was placed in a desiccator for 25 - 30 min to cool and the dry weight of pods was expressed in $\mathrm{g} /$ pod. Moisture content of pod was calculated by subtracting the weight of dried pod from the fresh weight and expressed as percentage to the weight of fresh pods. The growth rate ( $\mathrm{cm}$ or $\mathrm{mm} /$ day) of pod was calculated by using the method given by Briggs et al. (1920) per day basis. Pod chlorophyll content was estimated by using acetone method (Arnon, 1949).
At every stage (DAA), twenty-five seeds each in four replications were taken to measure seed diameter $(\mathrm{mm})$ by using a stereo zoom microscope. Immediately after harvesting of pods, the seeds were manually extracted, and the parameters viz., seed weight (fresh and dry weight), and moisture content (ISTA, 2015) were determined.

Moisture
$\begin{aligned} & \text { content of } \\ & \text { seed }(\%)\end{aligned}=\frac{1}{\text { dry weight }}$

Four replicates of 100 seeds from each stage of maturation (DAA) were subjected to a germination test (ISTA, 2015) by using sand media, and the set up was placed in a germination room maintained at $25 \pm 2{ }^{\circ} \mathrm{C}$ and $95 \pm 3 \% \mathrm{RH}$ with fluorescent light. At the end of the fourteenth day (test period), the number of normal seedlings that emerged in each replication were counted, and the mean was expressed in percentage. Seeds that remained hard and unimbibed were counted, and the mean was expressed as the percentage of hard seeds. The speed of germination was determined by adopting the method given by Maguire, 1962 (Eqn. 2). Ten normal seedlings from each replication were subjected for measuring the following parameters: root length $(\mathrm{cm})$, shoot length $(\mathrm{cm})$, and dry matter production (g/10 seedlings). Vigor index (VI) was calculated by Abdul-Baki and Anderson (1973) method, and the values were expressed as a whole number (Eqn. 3 \& Eqn. 4). Protein content (\%) of seed was estimated by adopting Ali-khan and Youngs method (1973), and the electrical conductivity (EC) of seed was measured by soaking twenty-five seeds in $50 \mathrm{ml}$ of distilled water from each stage (DAA) for $24 \mathrm{~h}$ in four replicates. The EC of seed leachate was expressed as $\mu \mathrm{S} / \mathrm{m}$ (Presley, 1958).

Speed of germination $=\left(X_{1} / Y_{1}\right)+\left(X_{2}-X_{1} / Y_{2}\right)+\ldots . .+$ $\left(X_{n}-\left[X_{n}-1\right] / Y_{n}\right)(2)$

Where, $X n=$ No. of seeds germinated on $n^{\text {th }}$ count and $Y n=$ No. of days from sowing to $n^{\text {th }}$ count.

Vigour index I = Germination (\%) x Mean seedling length $(\mathrm{cm})$

Vigour index $\mathrm{I}=$ =Germination (\%) x Dry matter production (g/10 seedlings)

Statistical analysis: Statistical analysis was done as per Gomez and Gomez (1984). Before statistical analysis, the per cent data were transformed into angular (arcsine) value. At $5 \%(P=0.05)$, the critical difference (CD) was worked out, and wherever ' $\mathrm{F}$ ' value is non-significant, it is denoted by "NS".

\section{RESULTS AND DISCUSSION}

Pod characteristics during maturity stages: At each stage of maturity, highly significant changes 
were found for all the assessed pods. Due to intense cellular division and expansion, there was a progressive increase in pod length up to 30 DAA, and the maximum pod length $(18.4 \mathrm{~cm})$ was attained at 30 DAA (Figure 1).

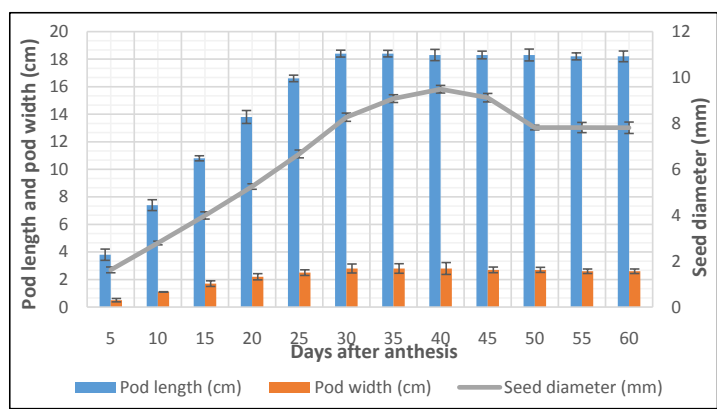

Figure 1. Effect of maturity stages on pod length, pod width and seed diameter in winged bean $\mathrm{cv}$. Revathi

After that, there was no significant increase in pod length, and its growth was ceased. Pod width also followed the similar increasing trend as that of pod length, and the maximum pod width $(2.8 \mathrm{~cm})$ was observed at 30 DAA (Figure 1). A similar trend of increasing pod length and width was reported in Lablab purpureus by Das and Fakir (2014). Pod growth rate (length and breadth) was maximum between 5 DAA and 10 DAA, after which it gradually decreased and altogether ceased after 30 DAA (Figure 2). Deshmukh et al. (2011) reported a similar trend of growth rates in developing cowpea pods.

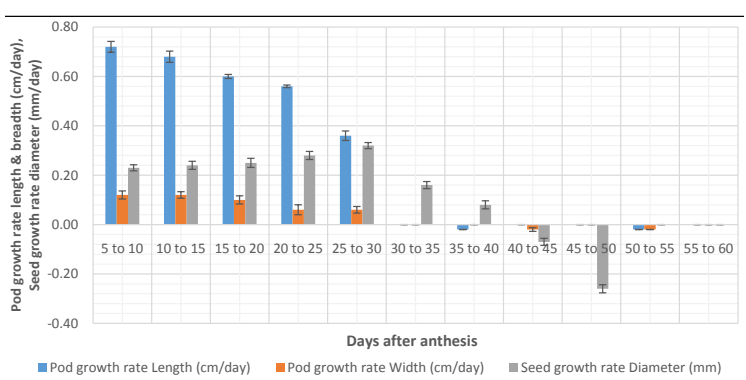

Figure 2. Effect of maturity stages on pod growth rate length $\&$ width, and seed growth rate diameter in winged bean cv. Revathi

Three distinctive stages of pod development were observed in the study. During the first stage of pod development between 5 DAA and 30 DAA, there was a rapid increase in dry weight of the pod, which was coincided with a moisture content of $57.9 \%$ at 30 DAA. The second stage of pod development occurred at 30 DAA to 50 DAA, and it was categorized by a rapid drop in fresh weight coincided with a reduction in the moisture content of $28.9 \%$ at 50 DAA. The third stage of pod development was happened between 50 DAA and 60 DAA, categorized by gradual loss of moisture concurred with a moisture content of $18.7 \%$ at 60 DAA (Figure 3 ).
Ofori and Klogo (2005) also reported the three stages of pod development in yard long bean as 0 to 5 DAA, 15 to 25 DAA, and 25 to 30 DAA, respectively.

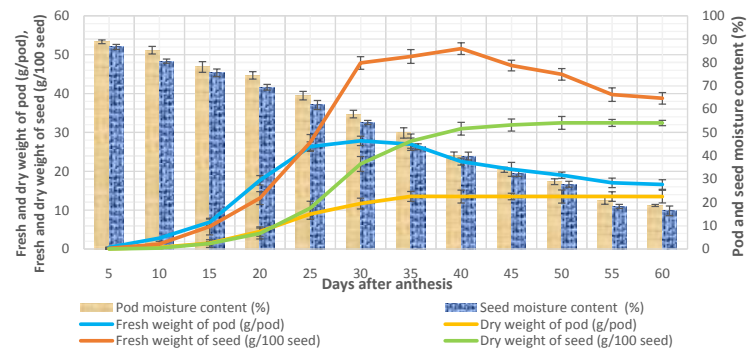

Figure 3. Effect of maturity stages on fresh and dry weight of pod, fresh and dry weight of seed, and moisture content of pod and seed in winged bean cv. Revathi

The fresh weight of the pod increased rapidly during pod development, and the maximum fresh weight ( $27.84 \mathrm{~g} /$ pod) was attained at 30 DAA, which was positively correlated with pod size. An increase in fresh weight was due to the simultaneous accumulation of dry mass and water uptake. A similar trend of increasing dry weight was observed, and the dry weight reached the maximum (13.54 g) at 35 DAA while the fresh weight declines from 30 DAA.

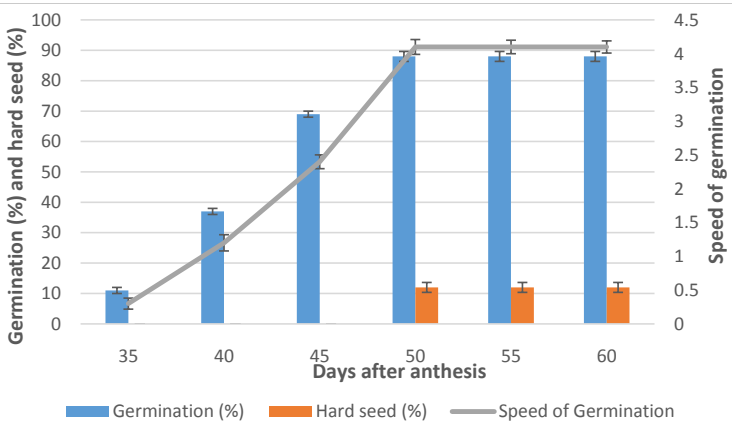

Figure 4. Effect of maturity stages on germination (\%), hard seed (\%) and speed of germination in winged bean cv. Revathi

It was observed that the fresh weight and dry weight increased simultaneously, and as the maturation progresses, the fresh weight decreased whereas the dry weight increased for a further period (Figure 3). The decrease in fresh weight was due to the simultaneous loss of moisture content and lack of cell division in the pod. Sandhan (1982) also reported similar results in field bean.

The results also revealed that pod moisture content decreased from $88.9 \%$ to $18.7 \%$ during the maturity stages, and the decrease in moisture content is due to the replacement of water molecules by starch and other large molecules with low hydration capacity (Figure 3). A similar trend of decline in pod moisture content with the advancement in maturity stages was reported in cluster bean by Renugadevi et al. (2006). 
Physical characteristics of seed during maturity stages: According to Demir et al., 2008, stage of maturity at harvest is one of the most critical factors that influence the final quality of seeds. In accordance with TeKrony and Hunter (1995), maximum seed quality may be achieved at the end of the seed filling period.

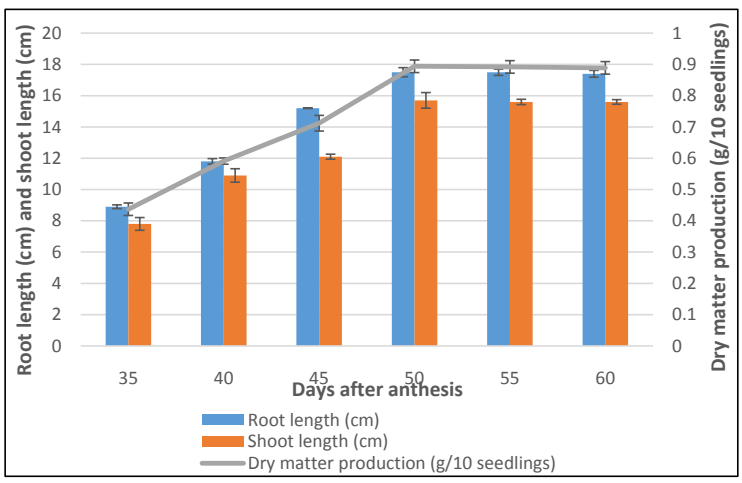

Figure 5. Effect of maturity stages on root length, shoot length and dry matter production in winged bean cv. Revathi

During seed maturity stages, four phases were observed. During phase I and II (5 DAA to 30 DAA), there was rapid cell division and expansion, which results in increases in seed size (diameter). Kathiravan (2001) also reported a similar trend in lablab CO 1. Seed growth rate followed an increasing trend, and the maximum growth rate $(0.32 \mathrm{~mm} /$ day) was attained from 25 DAA to 30 DAA, and thereafter it decreased (Figure 2). A similar trend of growth rates was reported by Deshmukh et al. (2011) in developing cowpea pods. There were steep increases in seed size, seed weight (fresh and dry weight) during this phase. In this phase, moisture content decreased slowly because water is the nutrient transporting vehicle from parent to developing seeds (Figure 3). Similar results were reported by Fakir et al. (2013) in lignosus bean.

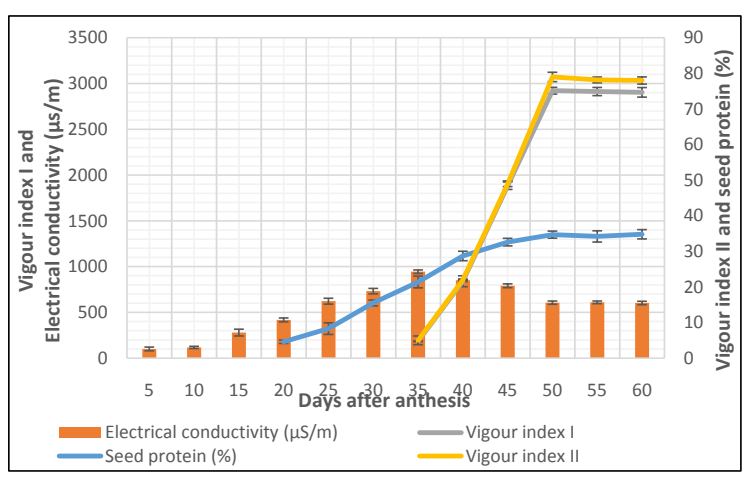

Figure 6. Effect of maturity stages on vigor index I, vigor index II, seed protein (\%) and electrical conductivity in winged bean cv. Revathi

At phase III (30 DAA to 50 DAA), fresh weight increased slowly and attained maximum at 40 DAA (51.58 g/100 seed), which was coincided with maximum seed size (9.49 $\mathrm{mm}$ ) at 40 DAA (Figure 1 \& 3). After $40 \mathrm{DAA}$, the fresh weight and the seed size decreased due to rapid dehydration of seed and lack of cell division while the dry weight increased for a further period of up to 50 DAA. Seed size reduction was more obvious in the leguminous seed. Maximum dry weight $(32.47 \mathrm{~g} /$ pod) was attained at 50 DAA, and after that, there was no increase in dry weight due to disintegration between source and sink (Figure 3). Nedeva and Nikolova (1999) reported similar results in developing wheat seeds. There was a rapid loss of moisture during this phase due to a lack of cell division and replacement of moisture by reserve accumulation.

At phase IV (50 DAA to 60 DAA), the moisture content decreased gradually and attained hygroscopic equilibrium at 27 DAA (Figure 3). The moisture content changes were associated with variations in relative humidity. The four phases of maturity stages in winged bean was found following Adams and Rinne in soybean (1980).
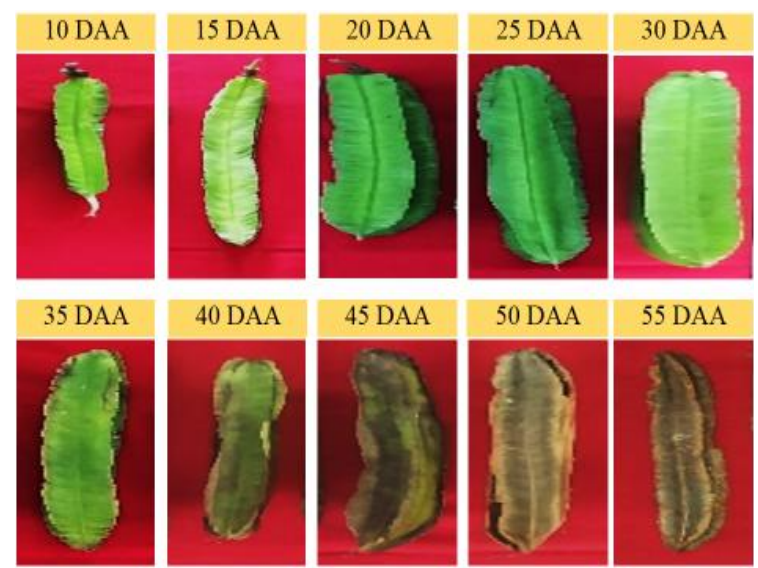

\section{Figure 7. Pod maturity stages}

Physiological and biochemical characteristics of seed during maturity stages: Khan (1977) stated that the prime indicator of seed quality is the germination capacity, and the final produce will become seed only after regeneration capacity. Figure 4 shows that developing seed started to germinate at 35 DAA to an extend of $11 \%$, and the germination per cent increased significantly with maturity stages. Maximum germination per cent (88\%) was attained at 50 DAA with a hard seed of $12 \%$, which was coincided with maximum dry matter accumulation (32.47 g/pod). There was no significant difference in germination per cent after 50 DAA. The speed of germination also followed a similar increasing trend and reached maximum (4.1) at 50 DAA (Figure 4). A similar trend of maximum germination coincided with maximum dry weight was reported by Anurag et al. (2009) in mungbean.

Under given environmental conditions, root length and shoot length reveals the performance 
of the seed, and it is the measure of seedling vigor (Woodstock and Combs, 1964). The present study shows that the root length and shoot length increased with advances in maturity stages, and the maximum seedling length was attained at 50 DAA, which was concurred with the maximum dry weight of seed (Figure 5). The maximum dry matter production ( $0.894 \mathrm{~g} / 10$ seedlings) was attained at 50 DAA, and thereafter, it was slightly reduced due to the development of inbuilt mechanism involved in the disorganization of cell organelles after physiological maturity (Figure 5). The calculated vigor index was maximum at 50 DAA, which was coincided with maximum dry weight and germination per cent of the seed due to seed membrane organization and increases in enzyme synthesis (Figure 6). Krishnakumary (2012) reported similar findings in vegetable cowpea varieties.

Protein content during the maturity stages showed the increasing trend and reached maximum $(34.7 \%)$ at 50 DAA, which was coincided with the maximum dry weight of the seed (Figure 6). The electrical conductivity (EC) of seeds increased up to 35 DAA due to poor membrane stability. Thereafter, EC decreased and finally reached stability at 50 DAA $(606.3 \mu \mathrm{S} / \mathrm{m})$, which was coincided with the maximum germination capacity of seeds (Figure 6). Simon and Mills (1983) also reported that the poor quality seeds have poor membrane stability, and it became stable at physiological maturity of seeds.

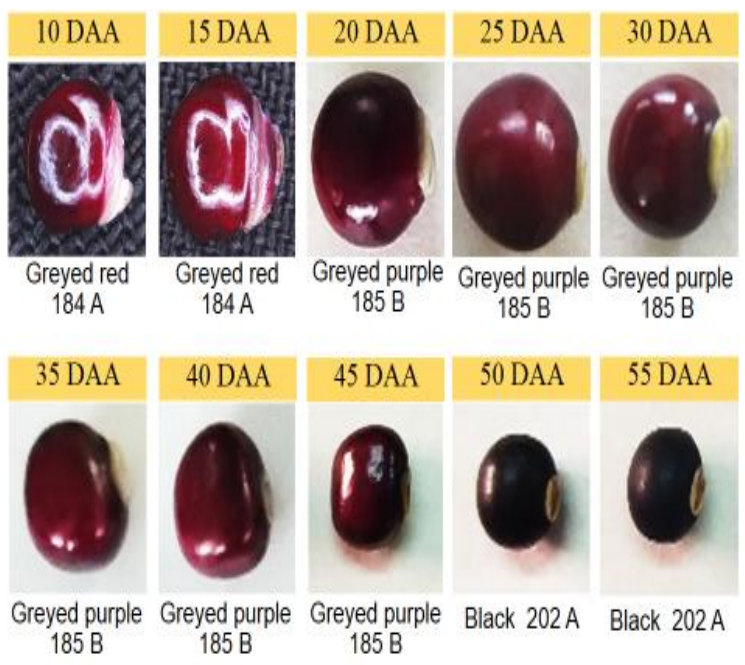

\section{Figure 8. Seed maturity stages}

The visual index of seed maturation is pod and seed color. As the seed matures, the vascular system of the integumentary was destroyed, which was coincided with the turning of seed coat color (Carlson, 1973). In this study (Figure $7 \& 8$ ), it was observed that pod color changes from green color at 10 DAA to brown color at 50 DAA and the seed color changes from greyed red group (184 A) at 10 DAA to black group (202 A) at 50 DAA. The color indicated was based on the Royal Horticultural Society (RHS) color chart. The optimum time for harvesting seeds at physiological maturity was indicated by the brown color of pods and black group (202 A) of seeds at 50 DAA, which was coincided with maximum seed quality characters.

\section{CONCLUSION}

Winged bean, being an underutilized proteinrich crop, determined for its seed quality during the maturity stages revealed that physiologically matured seeds were obtained from the pods harvested at 50 DAA with pod and seed moisture content of $28.9 \%$ and $27.8 \%$, respectively. The indices for physiological maturity were maximization of seed dry weight (32.47 g/100 seed), higher germination per cent (88\%), and maximum seedling vigor. The visual indices for maturation were turning of the pod to brown color and the seed to black group (202 A). Hence it is recommended to harvest pods at 50 DAA for obtaining the maximum quantity of quality seeds.

\section{REFERENCES}

Abdul-Baki, A.A. and J.D. Anderson. 1973. Vigor determination in soybean seed by multiple criteria. Crop Science, 13(6): 630-633.

Adams, C.A. and R.W. Rinne. 1980. Moisture content as a controlling factor in seed development and germination. International Review of Cytology, 68(1).

Ali-Khan, S.T., and C.G. Youngs. 1973. Variation in protein content of field peas. Canadian Journal of Plant Science, 53(1): 37-41.

Allen, O.N. and E.K. Allen. 1981. The Leguminosae, a source book of characteristics, uses, and nodulation. University of Wisconsin Press, Madison, Wisconsin, pp. 812.

Amoo, I.A., Adebayo, O.T. and A.O. Oyeleye. 2006. Chemical evaluation of winged beans (Psophocarpus tetragonolobus), Pitanga cherries (Eugenia uniflora) and orchid fruit (Orchid fruit myristica). African Journal of Food, Agriculture, Nutrition and Development, 6(2).

Anurag, P. J., Chaurasia, A. K. and N. R. Rangare. 2009. Physiological maturity in mungbean (Vigna radiata L. Wilczek) cultivars as influenced by differing harvest dates. Agricultural Science Digest, 29(3): 182-185.

Arnon, D.I. 1949. Copper enzymes in isolated chloroplasts. Polyphenoloxidase in Beta vulgaris. Plant Physiology, 24(1): 1.

Briggs, G. E., Kidd, F., and C. West. 1920. A quantitative analysis of plant growth: Part II. Annals of applied Biology, 7(2-3): 202-223.

Carlson, J.B. 1973. Morphology. In Soybeans: Improvement, Production, and Uses. B.E. Caldwell (Ed.). American Society of Agronomy, Agronomy Monograph 16, Madison, Wisconsin, pp. 17-95. 
Cheng, A., Raai, M.N., Zain, N.A.M., Massawe, F., Singh, A. and W.A.A.Q. I. Wan. 2019. In search of alternative proteins: unlocking the potential of underutilized tropical legumes. Food Security, 1-11.

Copeland, L.O. and M.B. McDonald. 1995. Principles of Seed Science and Technology ( $3^{\text {rd }}$ edition), Chapman and Hill, New York.

Das, S.S. and M.S.A. Fakir. 2014. Pod growth and seed composition in two genotypes of Lablab purpureus. Legume Research-An International Journal, 37(3): 306-310.

Demir, I., Ashirov, A.M. and K. Mavi 2008. Effect of seed production environment and time of harvest on Tomato (Lycopersicon esculentum) seedling growth. Research Journal of Seed Science, 1(1): 1-10.

Deshmukh, D.V., Mate, S.N., Bharud, R. W. and P. N. Harer. 2011. Analysis of pod and seed development in cowpea [Vigna unguiculata (L.) Walp]. Am. Eurasian. J. Agron, 4: 50-56.

Fakir, M.S.A., Das, S.S. and F. Islam. 2013. Seed growth and seed quality in Dipogon lignosus (L.) Verdc. bean. Legume Research-An International Journal, 36(5): 380-386.

Finkelstein, R.R. 2010. The role of hormones during seed development and germination. Plant hormones, Springer, pp. 549-573.

Gatehouse, A. M.R., Hoe, D.S., Flemming, J.E., Hilder, V. A. and J. A. Gatehouse. 1991. Biochemical basis of insect resistance in winged bean (Psophocarpus tetragonolobus) seeds. Journal of the Science of Food and Agriculture, 55(1): 63-74.

Gomez, K.A. and A.A. Gomez. 1984. Statistical Procedures for Agricultural Research, $2^{\text {nd }}$ edition, John Wiley \& Sons, New York, USA.

ISTA. 2015. International Rules for Seed Testing. International Seed Testing Association,Bassersdorf, Switzerland. http://www. seedtest.org/.

Kathiravan, M. 2001. Seed technological studies in Lablab CO 1 (Lablab purpureus (L.) Sweet var. typicus Prain). M.Sc. (Ag.) thesis, Tamil Nadu Agricultural University, Coimbatore, India.

KAU (Kerala Agricultural University). 2011. Package of practices recommendations: Crops (14 ${ }^{\text {th }}$ edition). Kerala Agricultural University, Thrissur.

Khan, A.A. 1977. The physiology and biochemistry of seed dormancy and germination. Elsevier Scientific Publications Company, Amsterdam, pp. 77-175.

Krishnakumary, K. 2012. Pattern of Fruit and Seed Development in Vegetable Cowpea Varieties. Legume Research-An International Journal, 35(1): 53-55.

Maguire, J.D. 1962. Speed of germination-Aid in selection and evaluation for seedling emergence and vigor. Crop Science, 2(2): 176-177.

Mahto, C.S. and R. Dua. 2009. Genetic divergence for yield contributing traits in winged bean [Psophocarpus tetragonolobus L.(DC)]. Indian Journal of Plant Genetic Resources, 22(3): 239242.
Marcos-Filho, J., Chamma, H.M.C.P., Casagrande, J.R.R., Marcos, E.A. and M.A.B. Regitano-D'Arce. 1994. Effect of harvesting time on seed physiological quality, chemical composition and storability of soybeans. Scientia Agricola, 51(2): 298-304.

Massawe, F., Mayes, S. and A. Cheng. 2016. Crop diversity: an unexploited treasure trove for food security. Trends in Plant Science, 21(5): 365-368.

NAS (National Academy of Sciences). 1981. The winged bean: a high protein crop for the tropics, $2^{\text {nd }}$ edition, National Academy Press, Washington.

Nedeva, D. and A. Nikolova. 1999. Fresh and dry weight changes and germination capacity of natural or premature desiccated developing wheat seeds. Bulgarian Journal Plant Physiology, 25(1-2): 3-15.

Ofori, K. and P.Y. Klogo. 2005. Optimum time for harvesting yardlong bean (Vigna sesquipedalis) for high yield and quality of pods and seeds. Journal of Agriculture Social Sciences, 1(2): 86-88.

Presley, J. T. 1958. Relation of protoplast permeability to cotton seed viability and predisposition to seedling disease. Plant Disease Reporter, 42(7): 852.

Renugadevi, J., Natarajan, N. and P. Srimathi. 2006. Studies on seed development and maturation in cluster bean (Cyamopsis tetragonoloba). Madras Agricultural Journal, 93(7-12): 195-200.

Sandhan, M. 1982. Seed development and maturation, production and storage studies in field bean [Lablab purpureus (L.) Sweet var. lignosus (L.) Prain]. M. Sc. (Ag.) thesis, Tamil Nadu Agricultural University, Coimbatore, India.

Simon, E. W. and L.K. Mills. 1983. Imbibition, leakage and membranes. In Mobilization of reserves in germination, Springer, pp. 9-27.

Singh, M., Dubey, R.K., Koley, T.K., Maurya, A., Singh, P.M. and B. Singh. 2019. Valorization of winged bean (Psophocarpus tetragonolobus (L) DC) by evaluation of its antioxidant activity through chemometric analysis. South African Journal of Botany, 121: 114-120.

TeKrony, D.M. and J.L. Hunter. 1995. Effect of seed maturation and genotype on seed vigor in maize. Crop Science, 35(3): 857-862.

Verdcourt, B. and P. Halliday. 1978. A revision of Psophocarpus (Leguminosae-PapilionoideaePhaseoleae). Kew Bulletin, 191-227.

Vidigal, D.D.S., Dias, D.C.F.D.S., Dias, L. A. D. S., and F.L. Finger. 2011. Changes in seed quality during fruit maturation of sweet pepper. Scientia Agricola, 68(5): 535-539.

Woodstock, L. W. and M. F. Combs. 1964. A comparison of some possible indices of seedling vigor in corn. Proceedings of the Association of Official Seed Analysts, 54: 50-60. 